\title{
UPAYA PENINGKATAN KUALITAS HIDUP BAGI REMAJA PUTUS SEKOLAH STUDI KASUS DI PANTI SOSIAL BINA REMAJA (PSBR) TARUNA JAYA
}

\author{
Zulfahmi \\ Yayasan Sayap Ibu \\ Email: fachmie.zul@gmail.com
}

Received: 9th August 2018; Revised: 12th October 2018; Accepted: 15th December 2018

\begin{abstract}
A number of Indonesian children have experienced a dropped out school and the phenomenon seems increasing each year. This problem is in need of a resolve, especially from the local government. Due to various reasons of children dropping out, there is a need for a coaching scheme from institutions or organizations involved in this type of cases. Efforts are needed to improve the quality of life for teenagers with situation, i.e., the Taruna Jaya Social Care Institution for Youth (PSBR). This study uses a descriptive qualitative approach, while data collection, compilation, and report of the findings by a descriptive analysis method. The results of the research show that in an effort to provide skills for the school dropouts, PSBR conducts a skill trainings consisting of five majors, namely automotive, welding, air conditioning, salon and sewing. Skill training is carried out for six months with a portion of the curriculum $70 \%$ of practice and 30\% theory. To support personality development, a social, mental and spiritual guidance are also provided. The study concludes that the training conducted at PSBR has a positive effects due to its skills training orientation in addition to a spiritual and mental guidance provision.
\end{abstract}

Keywords: Teenagers, School Dropout, Quality of Life, PSBR.

Abstrak. Begitu banyaknya anak Indonesia yang putus sekolah dan setiap tahun semakin meningkat, seyogianya permasalahan ini perlu dicarikan jalan keluarnya, teruma pemerintah setempat. Sebab anak putus sekolah memiliki alasan yang berbeda-beda, sehingga perlu pembinaan dari lembaga atau oranisasi yang memang menggeluti kasus sepert ini. Karena itu dibutuhkan upaya meningkatkan kualitas hidup bagi remaja putus sekolah, salah satunya sepertiyang dilakukan oleh Panti Sosial Bina Remaja (PSBR) "Taruna Jaya". Penelitian ini, menggunakan pendekatan kualitati deskriptif, dalam mengambil data, menyusun, dan melaporkan temuan penulis menggunakan metode deskriptif analisis. Hasil dari penelitan yakni dalam upaya memberikan keterampilan bagi anak putus sekolah, PSBR melakukan pelatihan yang terdiri dari lima jurusan ini yaitu otomotif, las, ac, salon dan menjahit. Pelatihan keterampilan dilakukan selama enam bulan dengan porsi kurikulum $70 \%$ untuk praktek dan $30 \%$ untuk teori. Untuk menunjang keperibadian juga diberikan bimbingan sosial, mental dan spiritual serta diberikan bimbingan social, bimbingan mental dan spiritual. Dari hasil penelitian yang menggunakan metode kualitatif ini, peneliti menyimpulkan bahwa pelatihan yang dilakukan di PSBR sangat baik karena melakukan pelatihan keterampilan dengan memberikan juga bimbingan spiritual dan mental.

Kata Kunci: Remaja, Putus Sekolah, Kualitas Hidup, PSBR 


\section{Pendahuluan}

Pendidikan menjadi salah faktor penting bagi seseorang untuk menggapai kesuksesan dalam menjalani kehidupannya. Semakin baik pendidikan yang didapkan, sebakin terbuka lebar kesempatan untuk mendapatkan kualitas hidup yang baik pula. Pengertian putus sekolah (Abied, 2009) adalah seseorang yang telah masuk dalam sebuah lembaga pendidikan baik itu pada tingkat SD, SMP, maupun SMA untuk belajar dan menerina pelajaran tetapi tidak sampai tamat atau lulus kemudian mereka berhenti atau keluar dari sekolah. Kemudian seseorang juga bisa dikatakan putus sekolah dan dapat pula diartikan sebagai Drop-Out (DO) yang artinya bahwa seorang anak didik yang karena sesuatu hal, biasa disebabkan karena malu, malas, takut, sekedar ikut-ikutan dengan temannya atau karena alasan lain sehingga mereka putus sekolah di tengah jalan.

Dalam Pasal 1 ayat 1 Undang-undang Nomor 23 tahun 2014 tentang Perlindungan Anak dikatakan bahwa yang dimaksud dengan anak adalah seseorang yang belum berusia 18 (delapan belas) tahun, termasuk anak yang masih dalam kandungan. Dan masa remaja adalah sebuah fase dimana seorang anak akan menuju masa dewasa, artinya seorang remaja dipastikan belum berumur 18 tahun.

Merujuk (Kemensos, 2006) ialah suatu periode dari masa anak-anak menjadi dewasa ketika manusia menguji berbagai peran yang mereka mainkan dan mengintegrasikan peran-peran itu ke dalam suatu persepsi diri, suatu identitas. (Soerjono Sekanto, 2001) dikatakan bahwa secara psikologis usia remaja merupakan umur yang dianggap "gawat", oleh karena yang bersangkutan sedang mencari identitasnya. Remaja lebih banyak memerlukan pengertian daripada sekedar pengetahuan saja. Karena remaja masih bersifat labil dalam keadaan apapun dan memerlukan pendampingan dalam setiap kesempatan. Masa remaja (O’Donnell, 2006), adalah masa transisi perkembangan antara masa kanak-kanak dan masa dewasa yang pada umumnya dimulai pada usia 12 atau 13 tahun dan berakhir pada usia akhir belasan tahun atau awal dua puluhan tahun.

Banyak remaja yang putus sekolah disebabkan oleh tidak mampu memenuhi tuntutan sistem sekolah karena keharusan bekerja (O'Donnell, 2006). Anak-anak lainnya menjadi pekerja anak karena tidak tersedianya sekolah, karena mereka tidak mampu membayar biaya sekolah, karena pendidikan 
yang ditawarkan berkualitas rendah atau dipandang tidak relevan atau karena lingkungan sekolah tidak bersahabat. Sementara sebagian anak terampas hak atas pendidikannya karena mereka mulai masuk ke pasar kerja terlalu dini, sementara yang lain masuk ke lapangan kerja secara prematur karena hak mereka untuk memperoleh pendidikan tidak secara efektif dijamin. Sangatlah mungkin bagi seorang anak untuk bekerja dan tetap bersekolah, namun hanya sedikit yang dapat melakukan keduanya itu. Hanya tujuh persen anak yang berusia 5-9 tahun, 10\% anak yang berusia 10-14 tahun dan $11 \%$ anak yang berusia 15-17 tahun yang tetap bersekolah sambil bekerja.

Penyebab utama pekerjaan di bawah umur bersifat struktural, dan berkaitan dengan kelemahan dalam sistem pendidikan, sistem sosial dan sistem ekonomi. Program-program penyesuaian sosial, privatisasi dan transisi ke ekonomi pasar telah memberi dampak yang sangat signifikan pada tingkat bersekolah dan pekerjaaan anak di beberapa negara. Meskipun demikian, faktor budaya dan hukum juga ikut memainkan peran. Di banyak negara, minimum usia untuk bekerja lebih rendah dibanding usia wajib masuk bangku sekolah, yang menyebabkan keadaan paradoks dimana anak memiliki hak untuk mendapatkan pekerjaan sementara pada saat yang sama secara hukum diwajibkan sekolah.

Sedangkan dalam Pasal 9 ayat 1 Undang-undang Nomor 23 tahun 2014 tentang Perlindungan Anak menyebutkan bahwa, "Setiap anak berhak memperoleh pendidikan dan pengajaran dalam rangka pengembangan pribadinya dan tingkat kecerdasannya sesuai dengan minat dan bakatnya." Dan dalam Pasal 48 juga dalam Undang-undang yang sama mengatakan bahwa, "Pemerintah wajib menyelenggarakan pendidikan dasar minimal 9 (sembilan) tahun untuk semua anak." Kemudian dalam pasal 49 juga mengakatakan bahwa, "Negara, pemerintah, keluarga, dan orang tua wajib memberikan kesempatan yang seluas-luasnya kepada anak untuk memperoleh pendidikan.”.

Melihat banyaknya remaja putus sekolah ini merupakan hal yang cukup mengkhawatirkan, pasalnya tdak hanya persoalan putus sekolah saja, masalah penting yang dihadapi oleh remaja cukup banyak, diantaranya adalah dengan timbulnya berbagai konflik dalam diri remaja (Indrayani dan Asmuji, 2014).

Pertama, Konflik antara kebutuhan untuk mengendalikan diri dengan kebutuhan untuk bebas dan merdeka. Remaja membutuhkan penerimaan sosial dan penghargaan serta kepercayaan orang lain kepadanya. Di lain pihak dia 
membutuhkan rasa bebas, karena dia merasa telah besar, dewasa dan tidak kecil lagi. Konflik antar kebutuhan tersebut menyebabkan rusaknya keseimbangan emosi remaja.

Kedua, Konflik antara kebutuhan akan kebebasan dan ketergantungan terhadap orangtua. Di lain pihak remaja ingin bebas dan mandiri, yang diperlukannya dalam mencapai kematangan fisik, tetapi membutuhkan orangtua untuk memberikan materi guna menunjang studi dan penyesuaian sosialnya. Konflik tersebut menimbulkan kegoncangan kejiwaan pada remaja sehingga mendorongnya mencari pengganti selain orangtuanya biasanya teman, guru ataupun orang dewasa lainnya dari lingkungannya.

Ketiga, Konflik antara kebutuhan seks dan ketentuan agama serta nilai sosial. Kematangan seks yang terjadi pada remaja menyebabkan terjadinya kebutuhan seks yang mendesak tetapi ajaran agama dan nilai-nilai sosial menghalangi pemuasan kebutuhan tersebut. Konflik tersebut bertambah tajam apabila remaja dihadapkan pada cara ataupun perilaku yang menumbuhkan rangsangan seks seperti film, sandiwara dan gambar.

Keempat, Konflik nilai-nilai, yaitu konflik antara prinsip-prinsip yang dipelajari oleh remaja dengan prinsip dan nilai yang dilakukan orang dewasa di lingkungannya dalam kehidupan sehari-hari.

Kelima, Konflik menghadapi masa depan. Konflik ini disebabkan oleh kebutuhan untuk menentukan masa depan. Banyak remaja yang tidak tahu tentang hari depan dan tidak tahu gambarannya. Biasanya pilihan remaja didasarkan atas pilihan orangtua atau pekerjaan yang populer di masyarakat.

Melihat peliknya permasalahan remaja putus sekolah, Pemerintah Provinsi DKI Jakarta berinisiatif menaungi panti bagi anak yang putus sekolah dengan memberikan dukungan sebagai bentuk upaya peningkatan kualitas hidup bagi remaja putus sekolah. Panti Sosial Bina Remaja (PSBR) "Taruna Jaya” Tebet, Jakarta Selatan ini menjaring anak putus sekolah dan memberikan bekal dalam menghadapi persaingan dalam dunia kerja. Karena itulah penulis tertarik untuk melihat bagaimana upaya peningkatan kualitas hidup bagi remaja putus sekolah di PSBR. Sehingga dapat dilihat apakah bentuk peningkatan kualitas hidup ini dapat membuat para remaja putus sekolah lulusan PSBR ini dapat bersaing di dunia kerja dengan lulusan pendidikan formal lain, sebagai usaha untuk meningkatkan kualitas hidup bagi para remaja putus sekolah. 


\section{Upaya Peningkatan Kualitas Hidup bagi Remaja Putus Sekolah \\ di Panti Sosial Bina Remaja (PSBR) Taruna Jaya \\ Zulfahmi}

\section{Metode}

Pendekatan yang digunakan dalam penelitian ini adalah pendekatan kualitatif, karena peneliti bermaksud meneliti secara mendalam. Dan Bogdan dan Taylor dalam (Salam, 2006), menjelaskan bahwa metodologi kualitatif adalah prosedur penelitian yang menghasilkan data deskriptif berupa kata-kata tertulis atau lisan dari orang-orang dan perilaku yang dapat diamati.

Sedangkan menurut (Nawawi, 1992) pendekatan kualitatif dapat diartikan sebagai rangkaian kegiatan atau proses menjaring informasi dari kondisi sewajarnya dalam kehidupan suatu objek dihubungkan dengan pemecahan suatu masalah baik dari sudut pandang teoritis maupun praktis. Penelitian kualitatif dimulai dengan mengumpulkan informasi-informasi dalam situasi sewajarnya untuk dirumuskan menjadi suatu generalisasi yang dapat diterima oleh akal sehat manusia. Oleh karena itu, pendekatan kualitatif ini dipilih oleh penulis berdasarkan tujuan penelitian yang ingin mendapatkan gambaran tentang cara peningkatan kualitas bagi remaja putus sekolah di Panti Sosial Bina Remaja (PSBR) “Taruna Jaya” Tebet.

Pada saat menganalis data hasil observasi dan wawancara, peneliti menginterpretasikan data yang ada kemudian menyimpulkannya. Dimana peneliti menggunakan metode deskriptif analisis yaitu cara melaporkan data dengan menerangkan, memberi gambaran dan mengklasifikasikan serta menginterpretasikan data yang terkumpul secara apa adanya kemudian disimpulkan. Nasir (Ghalia Indonesia, 1993) mengemukakan analisa data ialah merupakan bagian yang sangat penting dalam metode ilmiah, karena dengan analisa data tersebut dapat diberi arti dan makna yang berguna dalam masalah penelitian. Analisis data melibatkan upaya mengidentifikasi ciri-ciri suatu objek dan kejadian. Kategori dari analisa ini diperoleh berdasarkan fenomena yang tampak pada peningkatan kualitas hidup bagi remaja putus sekolah di Panti Sosial Bina Remaja “Taruna Jaya” Tebet Jakarta Selatan.

\section{Hasil dan Diskusi}

Begitu banyak persoalan pada remaja, terutama pada remaja putus sekolah yang membuat Indonesia merupakan bangsa dengan kuantitas penduduk yang sangat tinggi namun tidak diimbangi dengan kualitasnya. Padahal di Era globalisasi ini tidak saja memberikan dampak positif tetapi juga dampak negatif bagi kehidupan manusia. Dampak positif yang kita rasakan 
adalah berkembangnya sains dan teknologi yang sangat pesat namun sekaligus mengakibatkan berkembang dan meningkatnya kebutuhan-kebutuhan manusia. Salah satu konsekuensi dari pengaruh globalisasi ini adalah meningkatnya kebutuhan pendidikan agar manusia dapat menguasai dan mengendalikan teknologi.

Selain itu, manusia pada dasarnya disamping memiliki fitrah yang baik juga mempunyai fitrah yang buruk. Agar yang buruk tersebut tidak berkembang, maka dibutuhkan proses pendidikan juga agar fitrah yang baik dapat berkembang dengan baik. Dengan demikian proses pendidikan tersebut harus benar-benar berlandaskan pada tujuan pendidikan yang paling mendasar yaitu pendidikan untuk memanusiakan manusia.

Pendidikan merupakan salah satu modal dasar bagi manusia untuk dapat memenuhi kebutuhan lainnya. Oleh karena itu, pendidikan secara formal diberikan kepada manusia sejak masih anak-anak yaitu usia enam atau tujuh tahun dan tidak pernah dibatasi sampai kapan seseorang harus berhenti dalam menempuh pendidikan. Setiap pendidikan dan pelatihan bertujuan untuk meningkatkan kualitas sumber daya manusia. Kualitas sumber daya manusia sangat diperlukan pada semua hal.

Menurut (Sedarmayanti, 2001), peningkatan kualitas sumber daya manusia untuk berbagai keperluan: 1) Menyiapkan seseorang agar pada saatnya mampu diserahitugasyang sesuai; 2) Memperbaiki kondisi seseorangyang sudah diberi tugas dan sedang menghadapi tugas tertentu, sedangkan yang merasa ada kekurangan pada dirinya diharapkan mampu mengemban tugas sebagai mana mestinya; 3) Mempersiapkan seseorang untuk diberi tugas tertentu yang sudah pasti syaratnya lebih berat dari tugas yang dikerjakan; 4) Melengkapi seseorang dengan hal-hal yang mungkin timbul di sekitar tugasnya, baik yang langsung maupun yang tidak langsung berpengaruh terhadap pelaksanaan tugasnya; 5) Menyesuaikan seseorang kepada tugas yang mengalami perubahan karena berubahnya syarat untuk mengerjakan tugas untuk pekerjaan secara sebagian atau seluruhnya; 6) Menambah keyakinan dan percaya diri kepada seseorang bahwa dia adalah orang yang sesuai dengan tugas yang sedang diembannya; 7) Meningkatkan wibawa seseorang dari pandangan bawahan maupun orang lain baik teman sejawat maupun para relasinya.

Pemerintah DKI Jakarta menyadari hal tersebut, maka didirikanlah panti sosial remaja putus sekolah untuk melakukan pelatihan keterampilan bagi 


\section{Upaya Peningkatan Kualitas Hidup bagi Remaja Putus Sekolah \\ di Panti Sosial Bina Remaja (PSBR) Taruna Jaya \\ Zulfahmi}

remaja putus sekolah. Hal ini sesuai dengan visi dari PSBR “Taruna Jaya” sendiri yaitu menyelamatkan remaja dari ketelantaran agar dapat tumbuh kembang secara wajar dan mampu hidup mandiri.

Sejarah berdirnya PSBR Taruna Jaya (Arsip Lembaga PSBR Taruna Jaya) yakni dimulai Pada tahun 1960, berdasarkan Keputusan Menteri Sosial RI-: HUK-7-5-57 tanggal 2 November 1959 Departemen Sosial bersama-sama dengan UNICEF mengadakan penelitian yang disebut dengan nama "Accesment Planning Community of Indonesian Children Needs Survey" yang disingkat "APS", ke daerah lokasi, Tebet Jakarta Selatan, yang pada waktu itu merupakan daerah yang padat penduduknya dan tingkat perekonomiannya termasuk rendah.

Dari masyarakat tersebut ditemukan banyak sekali remaja yang tidak dapat melanjutkan pendidikannya ketingkat yang lebih tinggi (putus sekolah). Dari hasil penelitian tersebut pada tahun 1962 di daerah Tebet Jakarta Selatan, didirikanlah pusat kursus dengan nama "Pusat Keterampilan Serba Guna" yang memberikan berbagai macam keterampilan seperti montir, menjahit, mengetik, bahasa inggris, dan sebagainya. Karena banyaknya peserta kursus maka dilaksanakan pagi dan sore hari dan bersifat umum tidak terbatas pada remaja putus sekolah saja.

Menurut Arsip Lembaga PSBR Taruna Jaya, sejak tanggal 28 Maret 2002 Panti Sosial Bina Remaja "Taruna Jaya" Tebet, menjadi salah satu lembaga atau Unit Pelaksana Teknis (UPT) dari Dinas Sosial Propinsi DKI Jakarta dan bertanggung jawab langsung kepada Kepala Dinas Sosial Propinsi DKI Jakarta.

PSBR merupakan satu-satunya Lembaga Pemerintah di Propinsi DKI Jakarta yang memberikan pelayanan langsung kepada remaja bermasalah sosial (putus sekolah, terlantar dan anak jalanan). Hal ini dipertegas dengan dikeluarkannya Peraturan Gubernur Provinsi DKI Jakarta Nomor 293 Tentang Pembentukan Organisasi dan Tata Kerja Panti Sosial Bina Remaja Taruna Jaya. Dan salah satu pelayanan yang diberikan dalam upaya peningkatan kualitas hidup remaja putus sekolah adalah dengan menyelenggarakan pelatihan keterampilan yang sesuai dengan bidang atau minat yang dimiliki oleh para remaja putus sekolah. Dimana pelatihan ini diharapkan dapat menggantikan pendidikan mereka yang terputus sehingga dapat melakukan peningkatan kualitas hidup melalui pelatihan yang diberikan oleh PSBR.

Pelatihan memiliki kata dasar "latih" yang mendapatkan awalan "pe" yang berarti pendidikan untuk memperoleh kemahiran atau kecakapan, dan 
akhiran "an". Menurut Soekidjo Notoadmojo (Rineka, 2003) bahwa pelatihan ialah merupakan bagian dari suatu proses yang tujuannya untuk meningkatkan kemampuan psikomotorik meskipun didasari pengetahuan dan sikap. Dalam pelatihan peserta pelatihan dituntut untuk dapat meningkatkan kemampuannya setelah mengikuti suatu pelatihan.

Pelatihan merupakan peran edukasional yang paling spesifik, karena secara mendasar memfokuskan pada upaya mengajarkan pada komunitas sasaran tentang bagaimana untuk melakukan sesuatu, (Adi, 2002). Sedangkan menurut (Cordoso, 1995), pelatihan adalah usaha untuk memperbaiki performa pekerja pada suatu pekerjaan tertentu yang sedang menjadi tanggung jawabnya, supaya efektif biasanya pelatihan harus mencakup pengalaman belajar, aktivitas-aktivitas yang terencana dan didasari sebagai jawaban atas kebutuhan yang berhasil diindetifikasi secara ideal.

Dimana, kualitas sumber daya manusia menyangkut dua aspek, yaitu kualitas fisik dan non fisik yang menyangkut kemampuan bekerja, berpikir dan keterampilan-keterampilan lain. Tujuan dari peningkatan kualitas sumber daya manusia tidak luput dari proses pemberdayaan manusia itu sendiri. Pengembangan Masyarakat dan Intervensi Komunitas mengungkapkan bahwa proses pemberdayaan pada intinya membantu klien untuk memperoleh daya dalam mengambil keputusan dan mementukan tindakan yang akan dia lakukan antara lain dengan transfer daya dari lingkungannya (Isbandi, 2002).

\section{Masa Penerimaan dan Seleksi Calon Peserta}

Dalam mencari atau menerima peserta, PSBR melakukan sosialisasi kepada masyarakat melalui lembaga-lembaga terkait namun untuk sosialisasi secara khusus tidak ada. Setelah melakukan penerimaan peserta, PSBR melakukan seleksi dan wawancara pribadi kepada calon peserta. Seleksi sangat perlu dilakukan untuk mengetahui kemampuan calon peserta dan dari mana peserta tersebut berasal, juga untuk memenuhi kapasitas atau daya tampung PSBR sendiri. Setelah diseleksi surat-surat tersebut, kemudian dilakukan wawancara secara pribadi kepada calon peserta. Menurut Bambang alumni PSBR Jurusan Otomotif angkatan 79, wawancara itu biasanya seputar tujuan masuk PSBR dan wawancara tentang kehidupan calon peserta seperti pernah sekolah sampai tingkat apa dan sudah pernah bekerja atau belum. 


\section{Masa Pelatihan}

Adapun yang dilakukan oleh PSBR saat ini adalah memberikan pelatihan keterampilan yang di dalamnya juga diberikan bimbingan sosial dan bimbingan mental kepada para peserta pelatihan atau yang biasa disebut Warga Binaan Sosial (WBS). Pelatihan diadakan selama enam bulan untuk setiap angkatannya dengan sistem institutional mothering atau pola pengasuhan di dalam asrama dengan satu orang pembina asrama.

Adapun macam-macam pelatihan keterampilan yang diberikan di PSBR adalah otomotif (bengkel mobil dan motor), las (listrik dan karbit), menjahit (pakaian pria dan wanita), salon (tata rias dan kecantikan), memperbaiki AC (air conditioner).

Selain itu para WBS juga diberikan bimbingan sosial dan bimbingan mental serta spiritual setiap harinya, seperti kerja bakti dan lain sebagainya. Waktu pelatihan keterampilan di PSBR terbagi menjadi dua waktu yaitu pagi dan siang hari. Pada pagi hari jam pelatihan dimulai pada pukul 10.00 wib sampai pukul 12.00 wib setiap hari Senin sampai dengan hari Sabtu. Sedangkan untuk siang hari pelatihan dimulai pada pukul 14.00 sampai dengan pukul 16.00 wib setiap hari Senin sampai dengan hari Jum'at, karena pada hari Sabtu siang banyak para WBS yang meminta izin untuk pulang ke rumah dan biasanya mereka baru kembali ke PSBR pada Minggu sore.

Sedangkan untuk bimbingan sosial para WBS mendapatkannya setiap hari Senin sampai dengan Kamis pada pukul 08.30 wib sampai dengan pukul 10.00 wib dengan materi yang berbeda setiap harinya dari hari Senin sampai dengan hari Kamis. Biasanya hari Senin itu diberikan materi sistem usaha kesejahteraan sosial, hari Selasa materi tentang etika sosial, hari Rabu materi tentang pancasila dan kewarganegaraan, kemudian hari Kamisnya materi tentang kewirausahaan. Sedangkan untuk pelaksanaan bimbingan mental dan spiritual biasanya dilakukan setelah WBS melakukan shalat Maghrib berjamaah sampai dengan shalat Isya setiap harinya kecuali hari Sabtu dan Minggu karena banyak WBS yang pulang ke rumahnya masing-masing.

Untuk jumlah materi yang diberikan kepada peserta sesuai dengan jurusannya masing-masing. Menurut Saebun dan Bapak Taufik pendamping untuk jurusan salon kepada penulis mengatakan bahwa kurikulum pelatihan yang dipakai di PSBR dan pembagian waktu dalam pelatihan sesuai dengan instruktur masing-masing setiap jurusan jadi tidak ada kurikulum untuk 
pelatihan dari PSBR sendiri ataupun Dinas Sosial DKI Jakata.

Kemudian untuk kemampuan pesertanya sendiri, PSBR memberlakukan hal yang sama kepada semua peserta. Artinya PSBR menyamakan tingkat kemampuan semua peserta dalam mengikuti, padahal setiap peserta di PSBR berasal dari tingkat pendidikan yang bebeda-beda. Hal ini membuat peserta yang memiliki tingkat pendidikan yang rendah akan tetinggal dalam memahami materi yang diberikan.

\section{Masa Terminasi}

Para WBS juga mendapat program Praktek Belajar Kerja (PBK) atau yang biasa dikenal dengan Praktek Kerja Lapangan (PKL) di luar PSBR selama satu bulan di setiap bulan terakhir menjelang dari pelatihan tersebut berakhir. Dan untuk mencari tempat PKL tersebut, setiap WBS dibebaskan untuk mencarinya dengan sebelumnya melakukan survey ke lembaga tersebut dan kemudian setelah itu datang kembali dengan membawa surat dari PSBR untuk lembaga tersebut. Untuk mencari tempat PKL para WBS diberikan waktu selama dua minggu. Tetapi jika menjelang PKL ada WBS yang belum mendapatkan tempat PKL dan berdasarkan pemantauan instruktur bahwa WBS tersebut benar-benar mencari tempat PKL.

Pada saat melakukan PKL para instruktur melakukan monitoring kepada para WBS. Monitoring ini biasanya dilakukan oleh instruktur masing-masing jurusan. Menurut Hadi (warga binaan social) monitoring dilakukan kepada para WBS ketika melakukan PKL dan melakukan perjanjian dengan pihak bengkel dan PSBR mengenai hal-hal yang mungkin diperlukan.

Pertama, Peserta, peserta pelatihan di PSBR yang berjumlah 120 orang setiap angkatan, sebenarnya sudah cukup dan tidak terlalu banyak bila dibagi dengan jumlah jurusan yang ada. Numun setiap jurusan tidak merata jumlah pesertanya. Setiap peserta juga memiliki latar belakang pendidikan yang bebeda-beda, ada yang hanya lulusan SD, SMP dan ada juga yang telah lulus dari SMA. Dari latar belakang pendidikan yang berbeda itu dapat mempengaruhi suasana pelatihan, maksudnya peserta yang satu dengan yang lain akan berbeda dalam menangkap materi yang diberikan. Hal ini harus diperhatikan benar oleh instruktur pelatihan, karena jika peserta tidak mengerti apa yang disampaikan instruktur maka akan membuat pelatihan itu gagal.

Kedua, Lamanya Waktu Pelatihan, Pelatihan yang dilakukan di PSBR 


\section{Upaya Peningkatan Kualitas Hidup bagi Remaja Putus Sekolah \\ di Panti Sosial Bina Remaja (PSBR) Taruna Jaya \\ Zulfahmi}

selama enam bulan setiap angkatan seharusnya bisa menghasilkan lulusan yang benar-benar siap menghadapi pekerjaan yang sesuai dengan jurusannya. Karena di dalam lembaga-lembaga pelatihan swasta atau kursus, biasanya hanya diberikan waktu sangat singkat yaitu antara satu sampai dengan tiga bulan setiap angkatannya. Jadi, dengan kata lain waktu yang diberikan PSBR kepada peserta pelatihan lebih panjang dari lembaga pelatihan swasta atau kursus singkat yang sedang marak akhir-akhir ini.

Dari waktu enam bulan tersebut, waktu yang efektif untuk mendapatkan teori dan praktek di PSBR adalah sekitar empat bulan. Hal ini dikarenakan para peserta melakukan program PKL selama satu bulan di bulan terakhir dari pelatihan tersebut. Dalam kurun waktu empat bulan tersebut setiap pelatih akan membaginya ke dalam beberapa bagian.

Ketiga, Metode Pelatihan, metode yang dilakukan hanyalah dengan menggunakan metode ceramah. Hampir semua jurusan melakukan metode tersebut. Namun ada juga jurusan yang melakukan metode lain agar suasana kelas tidak bosan. Seperti yang dilakukan oleh jurusan salon yaitu melakukan metode diskusi atau yang mereka sebut dengan briefing setiap Senin pagi sebelum pelatihan dimulai dengan melibatkan semua WBS jurusan salon.

Menurut Sylvani Satuan Pelaksana Pembina Sosial, "PSBR melakukan sistem 75 \% praktek dan $25 \%$ teori." Jadi, seharusnya dengan porsi yang lebih besar untuk praktek, para peserta seharusnya juga lebih cepat memahami dan mengerti dari materi tersebut. Artinya peserta pelatihan seharusnya lebih cakap dalam melakukan praktek. Namun beberapa alumni PSBR juga berkata kepada penulis bahwa yang mereka dapatkan di PSBR hanya merupakan dasar-dasar dari jurusan-jurusan tersebut sedangkan untuk pengembangannya dilakukan di tempat kerja seperti PKL dan saat bekerja itu sendiri.

Untuk materi bimbingan sosial serta bimbingan spiritual dan mental sangat baik karena dapat membentuk peserta menjadi lebih saling menghargai antara peserta satu dengan yang lainnya. Materi tersebut bukan hanya memberikan motivasi untuk menjadi peserta lebih baik namun juga dapat mengubah pandangan dan pola pikir di kalangan para WBS. Seperti yang diungkapkan oleh alumni PSBR angkatan 79 kepada penulis bahwa, “...jadi gue bisa ngerasain mereka yang butuh. Yang apa lah orang kayak gitu pasti ada pelariannya. Jadi gue gak nganggep orang itu gini-gini nih. nah gitu, kalau itu dapet di sosialnya bang, bagus gue seneng sama ceramahnya bang...", (saya 
merasa mereka yang butuh, sebab orang seperti itu pasti cari pelarian. Jadi saya tidak anggap orang seperti itu seperti tampilannya. Karena dia dapat di lingkungan sosialnya. Dan saya senang pada ceramahnya.

Dengan kata lain, selain membangun sumber daya manusia yang berkualitas dari segi keterampilannya juga dibutuhkan membangun sumber daya manusia dari segi emosional dan spritualnya, begitulah yang PSBR lakukan untuk menciptakan sumber daya manusia yang berkualitas. Para alumni angkatan 79 sendiri yang setelah mengikuti pelatihan merasa bahwa rasa kebersamaan dalam kehidupan bersosial di PSBR sangat tinggi sehingga mereka terbawa sampai dengan mereka keluar dari PSBR.

Setelah memahami tahapan pelatihan yang dilaksanakan oleh PSBR, dimana dalam pelatihan keterampilan ini juga terdapat proses pemberian penilaian dan dasar penilaian bagi peserta, dan disertai juga dengan analisis terhadap penilaian yang diberikan kepada peserta.

\section{Proses Pemberian Penilaian}

Setelah selesai mengikuti pelatihan selama enam bulan, para peserta mendapatkan sertifikat dan daftar nilai dari PSBR. Di dalam daftar nilai ini peserta mengetahui berapa nilai yang mereka peroleh selama mengikuti pelatihan tersebut. Penilaian yang didapatkan oleh para peserta adalah penilaian setelah mereka melakukan semua kegiatan yang diberikan oleh PSBR. Mulai dari teori, praktek sampai dengan praktek kerja lapangan yang dilakukan di lembaga di luar PSBR. Setelah melakukan PKL biasanya para peserta menuliskan laporannya kepada pihak PSBR yang disebut karya tulis dan setelah itu baru kemudian para peserta melakukan ujian atau tes secara tertulis mengenai materi-materi yang bukan merupakan materi jurusan.

\section{Dasar Pemberian Penilaian kepada Peserta}

Yang menjadi kriteria PSBR dalam melakukan penilaian terbagi menjadi lima kelompok materi yaitu: 1) Kelompok Dasar. Kelompok ini terdiri dari: a) pendidikan moral pancasila; b) pembinaan keagamaan; c) sistem usaha kesejahteraan sosial; d) etika sosial; e) manajemen kewirausahaan; 2) Kelompok Inti. dalam kelompok ini materi diberikan oleh jurusannya masingmasing; 3) Karya Tulis. karya tulis dibuat setelah para peserta melakukan PBK atau PKL dan bersifat individu; 4) Praktek Belajar Kerja. Nilai dari materi ini diberikan oleh lembaga yang menerima para peserta untuk melakukan PBK 
ini. 5) Kelompok Penunjang, yang terdiri dari tanggung jawab kerja, disipslin, kerajinan, kejujuran, dan kerjasama.

Sedangkan untuk kelompok inti dari penilaian setiap jurusan berbeda-beda. Dari materi-materi penilaian di atas dapat disimpulkan bahwa yang menjadi bahan penilaian setiap jurusan adalah penilain teori dan praktek. Jadi, tidak hanya penilaian terhadap praktek saja namun teori juga diperlukan. Baik buruknya nilai yang diterima oleh peserta adalah akibat dari hasil evaluasi yang dilakukan oleh PSBR kepada peserta tersebut. Jika peserta tersebut jarang mengikuti pelatihan tetap diberi nilai namun dengan nilai yang kecil.

Setelah keluar dari PSBR untuk para alumni masih dilakukan monitoring menurut Wawancara dengan Bpk. Taufik Hidayat pendamping jurusan Salon di PSBR kepada penulis, "Kita pantau bisa melalui by phone bisa juga melalui kita dapet informasi dari perusahaan. Yang paling telat ya tiga bulan ya. Setelah mereka selesai satu bulan paling cepet karena begitu selesai mereka kan ada yang bekerja ada juga yang tidak mendapat pekerjaan sedang berusaha dan menunggu panggilan, nah kita bisa nelihat siapa saja yang sudah bekerja siapa saja yang belum siapa saja yang saat ini sedang menunggu panggilan kerja."

\section{Analisis Tentang Penilaian}

Setiap pelatihan yang dilaksanakan oleh berbagai lembaga pelatihan, pasti akan memberikan sertifikat kepada para pesertanya di akhir masa pelatihan tersebut. Begitu juga dengan PSBR yang memberikan sertifikat dan daftar nilai kepada para pesertanya. Untuk materi yang menjadi dasar pemberian penilain di PSBR terbagi menjadi lima kelompok materi.

Dalam memberikan nilai kepada peserta haruslah memiliki tiga aspek, yaitu, Aspek kognitif: Yang menjadi aspek kognitif dalam pemberian nilai di PSBR adalah kelompok materi praktek belajar kerja dan karya tulis. Karena dalam dua kelompok ini, para peserta dapat menjelaskan pengetahuannya melalui materi praktek belajar kerja dan kemudian dapat memberikan opini serta pemikirannya yang dituangkan dalam bentuk karya tulis. Aspek afektif: Yang menjadi aspek afektif dalam pemberian nilai di PSBR adalah kelompok materi inti atau kelompok materi dari jurusan masing-masing. Karena dalam kelompok materi ini dapat mewakilkan perasaan peserta pelatihan apa yang diinginkannya terhadap pelatihan tersebut. Aspek tingkah laku: Yang menjadi aspek tingkah laku dalam pemberian nilai di PSBR adalah kelompok materi 
dasar dan kelompok materi penunjang. Karena dalam dua materi ini dapat berpengaruh dan mengarahkan tingkah laku para peserta pelatihan.

\section{Kesimpulan}

Berdasarkan hasil temuan data dalam penelitian ini, maka penulis dapat meyimpulkan bahwa pelatihan keterampilan yang dilakukan di PSBR merupakan bentuk nyata dari upaya Pemerintah DKI Jakarta dalam rangka menyelamatkan remaja putus sekolah dari ketelantaran dan hidup yang tidak wajar sehingga dapat meningkatkan kualitas para remaja. Selain itu pelatihan di PSBR tidak hanya pelatihan keterampilannya saja yang diberikan namun juga diberikan pembekalan mental dan spiritual serta bimbingan sosial kepada para WBS untuk memandang masa depan yang lebih baik.

Pelaksanaan pelatihan keterampilan yang diadakan di PSBR, menitikberatkan pada praktek dengan porsi kurikulum $70 \%$ untuk praktek dan $30 \%$ untuk teori agar para peserta bisa lebih memahami apa yang dijelaskan saat pelatihan berlangsung. Selama pelatihan berlangsung tidak ada pengawasan yang ketat bagi para peserta, dan masih banyak peserta yang berada di asrama selama jam pelatihan. Pelatihan materi dilakukan selama enam bulan, selain pelatihan lainnya. Pelatihan terpotong dengan kegiatan atau pelatihan lainnya seperti jurusan salon memakai metode diskusi yang dilakukan satu minggu satu kali.

Untuk meningkatkan kualitas sumber daya manusia bukan hanya dari segi keterampilan saja tetapi juga harus diimbangi dengan kualitas mental dan spiritualnya karena jika seseorang memiliki keterampilan yang baik dalam suatu hal, tetapi tidak diimbangi dengan kualitas mental dan spritualnya yang baik maka orang tersebut jika mengalami suatu kesulitan akan langsung jatuh dan susah untuk bangkit kembali

\section{Daftar Pustaka}

D, Indriyani, \& Asmuji. (2014). Buku Ajar Keperawatan Maternitas. Yogyakarta: Ar-Ruzz Media.

Tim Penyusun. (2006). Intervensi Psikososial (Intervensi Pekerja Sosial Profesional). Jakarta: Departemen Sosial Direktoral Kesejahteraan Anak, Keluarga dan Lanjut Usia,

Sekanto, Soerjono. 2001 Sosiologi suatu pengantar. Jakarta: PT. Raja Grafindo 


\section{Persada.}

'Donnell, Mr. Dan 0. 2006. Perlindungn Anak, Sebuah Panduan Bagi Anggota Dewan Perwakilan Rakyat. UNICEF.

Salam, Syamsir. 2006. Metode Penelitian Sosial. Jakarta: UIN Jakarta Press.

Nawawi, Hadari. (1992). Instrumen Penelitian Bidang Sosial. Yogyakarta: Gajah Mada University Press.

Nasir, D, Mohammad (1993). Metode Penelitian. Jakarta: Ghalia Indonesia.

Sedarmayanti. (2001). Sumber Daya dan Produktifitas Kerja. Bandung: CV Mandar Maju.

Notoadmojo, Soekidjo. (2003). Pengembangan Sumber Daya Manusia. Jakarta: PT Rineka.

Adi, Isbandi Rukminto. (2002). Pemikiran Pemikiran Dalam Pembangunan Kesejahteraan Sosial. Jakarta: Lembaga Penerbit FE UI.

Cordoso, Gomes Faustino. (1995). Manajemen Sumber Daya Manusia. Yogyakarta: Andi Offset.

19 Persen Anak Usia Sekolah Putus Sekolah, diakses dari http://www. tempointeraktif.com/hg/nasional/2005/06/13/brk, 2005061362414,id.html

LAZ Portal Infaq Bantu Anak Putus Sekolah, diakses dari http://www.republika. co.id/berita/9552/LAZ_Portal_Infaq_Bantu_Anak_Putus_Sekolah

Sedikit Kepedulian Untuk Kesempatan Besar, diakses dari http://www. serunifoundation. org/journal_read.php?sxEntryID=5\&comments $=5$

Faktor Penyebab Putus Sekolah, diakses dari http://meetabied.wordpress. com/2009/10/30/faktor-penyebab-putus-sekolah/

Psikologi Remaja, diakses dari http://duniapsikologi.dagdigdug. com/2008/11/27/pengertian-remaja/ 